\title{
Flavanoids fromthe Stembark ofChisocheton pentandrus(Meliaceae)
}

\author{
Supriatno $^{1}$, Ace Tatang Hidayat ${ }^{1,2}$, Kindi Farabi ${ }^{1}$, Fajar Fauzi Abdullah ${ }^{1}$, Nurlelasari ${ }^{1}$, \\ Tati Herlina $^{1}$, Unang Supratman ${ }^{1,2}$,Khalijah Awang ${ }^{3}$ \\ ${ }^{1}$ Department of Chemistry, Faculty of Mathematics and Natural Sciences, \\ Universitas Padjadjaran, Jatinangor 45363, Indonesia \\ ${ }^{2}$ Central Laboratory of Universitas Padjadjaran, Jatinangor 45363, Indonesia \\ ${ }^{3}$ Department of Chemistry, Faculty of Science, University of Malaya, Kuala Lumpur 59100, Malaysia \\ E-mail: unang.supratman@unpad.ac.id
}

Received: October 2017; Revised:November 2017; Accepted: November 2017; Available Online: November2017

\begin{abstract}
Two flavanoid compounds, catechin (1) and epicatechin (2), have been isolated from the stembark of Chisocheton pentandrus. The chemical structure of compounds1and2were identified by spectroscopic data including, UV, IR, NMR $\left({ }^{1} \mathrm{H},{ }^{13} \mathrm{C}\right.$, DEPT $135^{\circ}$, HMQC, HMBC, ${ }^{1} \mathrm{H}-{ }^{1} \mathrm{H}$ COSY $)$ and MS and by comparing with previously reported spectral data. Compounds $\mathbf{1}$ and $\mathbf{2}$, were isolated in this plant for first time and showed no cytotoxic activity against MCF-7 breast cancer cells.
\end{abstract}

Keywords:Chisocheton pentandrus, catechin, epicatechin, Meliaceae, MCF-7.

DOI: http://dx.doi.org/10.15408/jkv.v3i2.6077

\section{INTRODUCTION}

The tropical plant of Chisocheton belong to Meliaceae family is a higher plant that can grow up to $25 \mathrm{~m}$ in height (Mabberly and Pannell, 1989).This plant is widespread in the tropical and subtropical countries including Indo-China, Papua New Guinea, Southern China, Thailand, Malaysia, Nepal, India, Bhutan and Myanmar (Vossen and Umali, 2002). Some of these plant species have been traditionally used as laxatives, medicinal and cosmetic ingredients as well as for toxins in fish (Lim, 2008). Chisocheton species were known to produce bioactive compounds with complex molecular structures such as erythrocarpine $\mathrm{E}$ and chisomecine A (Awang et al., 2007, Najmuldeen et al., 2011). Plant from this genus have been known to be a rich source of secondary metabolites including various sterols, terpenoids and alkaloids with biologically properties such as antifungal, antibacterial, antiviral, anti-inflammatory, and antiplasmodial agents (Mohamad et al., 2009, Joshi et al., 1987, Agbedahunsi et al.,
2004).During the course of our continuing search for novel secondary metabolites from Indonesia Chisocheton plants, we isolated and described a new limonoid, dysobinol, from the bark of $C$. macrophyllus (Nurlelasari et al., 2017) and a new lanostane-type triterpenoid, $3 \beta$-hydroxy-25-ethyl-lanost-9(11),24(24')-

diene, from the stembark of A. cumingianus (Katja et al., 2016). In the further search for novel compounds from Indonesia Chisocheton plants, recently we explore the phytochemistry of the stembark of $C$. pentandrus. The plantis a higher plant and mainly distributed in nothern part of Sulawesi in Indonesia (Inada et al., 1997; Mabberley et al., 1995). Its stembark has been used as an Indonesian folk medicine for reducing fever, moisturizing the lungs, and for treating contused wound (Heyne., 1982). Although secondary metabolite compounds of other Chisocheton plants have been investigated previously, the chemical constituents of $C$. pentandrus is yet to be reported. In this paper, we describe the isolation and structural elucidation of two flavanoids, $\mathbf{1}$ and $\mathbf{2}$. 


\section{MATERIAL AND METHODS}

\section{General Experimental Procedure}

Melting points were measured on an electrothermal melting point apparatus and are uncorrected. UV spectra were measured by using a TECAN Infinite M200 pro, with $\mathrm{MeOH}$. The IR spectra were recorded on a SHIMADZU IR Prestige-21 in $\mathrm{KBr}$. The mass spectra were recorded with a Waters Xevo QTOF MS. NMR data were recorded on a Bruker Topspin spectrometer at $500 \mathrm{MHz}$ for ${ }^{1} \mathrm{H}$ and $125 \mathrm{MHz}$ for ${ }^{13} \mathrm{C}$ using TMS as an internal standard. Column chromatography was conducted on silica gel 60. TLC plates were precoated with silica gel $\mathrm{GF}_{254}$ (Merck, $0.25 \mathrm{~mm}$ ) and detection was achieved by spraying with $10 \% \mathrm{H}_{2} \mathrm{SO}_{4}$ in $\mathrm{EtOH}$, followed by heating and under UV light at wavelength at 254 and $367 \mathrm{~nm}$.

\section{Plant Material}

The stem bark of $C$. pentandrus was collected in Bogor Botanical Garden, Bogor, West Java Province, Indonesia in June 2016. The plant was identified by the staff of the Bogoriense Herbarium, Bogor, Indonesia and a voucher specimen (No. Bo-104) was deposited at the herbarium.

\section{Plant Extraction}

Dried ground stembark $(1.8 \mathrm{~kg})$ of $C$. pentandruswas extracted with methanol exhaustively (14 L) at room temperature for 7 days. After removal of the solvent under vacuum, the viscous concentrated of $\mathrm{MeOH}$ extract $(340.01 \mathrm{~g})$ was first suspended in $\mathrm{H}_{2} \mathrm{O}$ and then partitioned with $n$-hexane, EtOAc, and $n$-butanol, successively. Evaporation resulted in the crude extracts of $n$-hexane $(10.90 \mathrm{~g})$, EtOAc $(25.18 \mathrm{~g})$, and $n$-butanol (228.63 g), respectively. The EtOAc soluble fraction $(25.18 \mathrm{~g})$ was fractionated by column chromatography on silica gel using a gradient $n$-hexane, EtOAc and $\mathrm{MeOH}$ to give eight fractions $(\mathrm{A}-\mathrm{H})$, combined according to TLC results. Fraction B (1.73 g) was subjected to column chromatography over silica gel using a gradient mixture of $\mathrm{CH}_{2} \mathrm{Cl}_{2}$-EtOAc (10:0-1:1) as eluting solvents to afford six subfractions (B1-B6). Subfraction B3 (460 mg) was chromatographed on a column of silica gel, eluted with $\mathrm{CH}_{2} \mathrm{Cl}_{2}$ :EtOAc $(7 ; 3)$, to give five subfractions (B3A-B3E). Subfraction B3B was separated on preparative TLC, eluted with $\mathrm{CH}_{2} \mathrm{Cl}_{2}:$ EtOAc (6.5:3.5), to give $\mathbf{1}(18.5 \mathrm{mg})$. Subfraction B3C (100 mg $)$ was chromatographed on a column chromatography of silica gel, eluted with $\mathrm{CH}_{2} \mathrm{Cl}_{2}:$ EtOAc (6.5:3.5), to give 2 (37.9 mg).

\section{RESULT AND DISCUSSION}

The methanol extract from the dried bark of $C$. pentandrus was concentrated and extracted successively with $n$-hexane, ethyl acetate and $n$-butanol The ethyl acetate extracts showed rich of flavonoid compound by detecting under uv light and $\mathrm{AlCl}_{3}$ reagent. By using flavonoid test to guide separations, the ethyl acetate fraction was separated by combination of column chromatography on silica gelG60 and preparative TLC on silica gel $\mathrm{GF}_{254}$ to afford two flavanoid compounds 1 and 2 .

Catechin (1). Yellow amorphous powder;m.p. $176-177^{\circ} \mathrm{C}$; UV $(\mathrm{MeOH}) \lambda_{\max } \mathrm{nm}$ (log ع) 275 (3.93), IR (KBr) $v_{\text {maks }}\left(\mathrm{cm}^{-1}\right) 3327$, 1570, 1156, 1051 and 827. 'H-NMR (DMSO$d_{6}, 500 \mathrm{MHz}$ ) and ${ }^{13} \mathrm{C}-\mathrm{NMR}$ (DMSO- $d_{6}, 125$ $\mathrm{MHz}$ ), see Tables 1; HR-TOFMS (positive ion mode) $m / z \quad 291.0878 \quad[\mathrm{M}+\mathrm{H}]^{+}, \quad$ (calcld. for $\mathrm{C}_{15} \mathrm{H}_{14} \mathrm{O}_{6}, \mathrm{~m} / \mathrm{z} 290.0787$ ).

Epicatechin (2). Yellow amorphous powder; m.p. $176-177{ }^{\circ} \mathrm{C}$; UV (MeOH) $\lambda_{\max }$ $\mathrm{nm}(\log \varepsilon) 276$ (3.94), IR (KBr) $v_{\text {maks }}\left(\mathrm{cm}^{-}\right.$ $\left.{ }^{1}\right) 3330,1550,1140,1045$ and 830. ${ }^{1} \mathrm{H}-\mathrm{NMR}$ (DMSO- $d_{6}, 500 \mathrm{MHz}$ ) and ${ }^{13} \mathrm{C}-\mathrm{NMR}$ (DMSO$d_{6}, 125 \mathrm{MHz}$ ), see Tables 1; HR-TOFMS (positive ion mode) $\mathrm{m} / \mathrm{z} 291.0878[\mathrm{M}+\mathrm{H}]^{+}$, (calcld. for $\mathrm{C}_{15} \mathrm{H}_{14} \mathrm{O}_{6}, \mathrm{~m} / 2290.0787$ ). 
<smiles>Oc1cc(O)c2c(c1)O[C@H](c1ccc(O)c(O)c1)[C@H](O)[C@H]2I</smiles>

Figure 1. Structures of Compounds 1 and 2.

Compounds 1 was obtained as a yellow powder. HR-TOFMS spectrum of 1showed $[\mathrm{M}+\mathrm{H}]^{+} \mathrm{m} / \mathrm{z} 291.0878$ (calcd $\mathrm{m} / \mathrm{z}$ 290.0787), which corresponded to the molecular formula of $\mathrm{C}_{15} \mathrm{H}_{14} \mathrm{O}_{6}$ thus requiring nine degrees of unsaturations. UV spectra in $\mathrm{MeOH}$ showed $\lambda_{\max } \mathrm{nm}(\log \varepsilon) 275$ (3.93), indicated the presence of flavan-3-ol skeleton (Andersen and Markham, 2006). The IR spectra showed absorption peaks at 3327 , $1570,1156,1051,827 \mathrm{~cm}^{-1}$ due to the presence of hydroxyl groups, $\mathrm{C}=\mathrm{C}$ aromatic rings, symmetric and asymmetric $\mathrm{C}-\mathrm{O}-\mathrm{C}$ and substituted benzene ring, respectively. The ${ }^{1} \mathrm{H}$ NMR spectrum of the compound showed the present of five olefinic methine protons, consist of twoprotons resonating at $\delta_{\mathrm{H}} 5.77$ and 5.76 (each $1 \mathrm{H}, \mathrm{d}, J=2.1 \mathrm{~Hz}$ ) were assigned for $\mathrm{H}-6$ and $\mathrm{H}-8$ in $\mathrm{A}$ ring, three protons resonating at $\delta_{\mathrm{H}} 6.83\left(1 \mathrm{H}, \mathrm{d}, J=1.7, \mathrm{H}-2^{\prime}\right)$, $6.61\left(1 \mathrm{H}, \mathrm{d}, J=8.6 \mathrm{~Hz}, \mathrm{H}-5^{\prime}\right)$, and $6.65(1 \mathrm{H}$, $\left.\mathrm{dd}, J=1.7,8.6 \mathrm{~Hz}, \mathrm{H}-6^{\prime}\right)$ were assigned to $\mathrm{ABC}$ proton-type in $\mathrm{C}$ ring and two oxygenated methine protons at $\delta_{\mathrm{H}} 4.41(1 \mathrm{H}, \mathrm{d}$, $J=7.8 \mathrm{~Hz}, \mathrm{H}-2)$ and $3.83(1 \mathrm{H}, \mathrm{dd}, J=7.8,5.5$, $\mathrm{H}-3)$, and one methylene proton at $\delta_{\mathrm{H}} 2.70$ $(1 \mathrm{H}, \mathrm{dd}, J=8.3,16.3 \mathrm{~Hz}, \mathrm{H}-4)$ and $2.37(1 \mathrm{H}$, $\mathrm{dd}, J=5.5,16.3 \mathrm{~Hz}, \mathrm{H}-4)$. Two meta-protons at ring A, evidenced by $J$ constant coupling of H-6 and H-8 $(2.1 \mathrm{~Hz})$ and HMBC correlations between H-6 to C-5, C-7, and H-7 to C-7, C-9 (Figure 2). A trisubstituted benzene was observed at $\delta_{\mathrm{H}} 6.83\left(1 \mathrm{H}, \mathrm{d}, J=1.7, \mathrm{H}-2^{\prime}\right), 6.61$ $\left(1 \mathrm{H}, \mathrm{d}, J=8.6 \mathrm{~Hz}, \mathrm{H}-5^{\prime}\right)$, and $6.65(1 \mathrm{H}, \mathrm{dd}, J=$ $1.7,8.6 \mathrm{~Hz}, \mathrm{H}-6^{\prime}$ ) and ${ }^{1} \mathrm{H}-{ }^{1} \mathrm{H}$ COSY cross peak $\mathrm{H}-5^{\prime} / \mathrm{H}-6^{\prime}$ (Figure 2). The flavan-3-ol skeleton in ring $\mathrm{C}$ was evidenced by ${ }^{1} \mathrm{H}-{ }^{1} \mathrm{H}$ COSY cross peak $\mathrm{H}-2 / \mathrm{H}-3 / \mathrm{H}-4$ also from $\mathrm{HMBC}$ correlation between $\mathrm{H}-2$ to $\mathrm{C}-9$ and $\mathrm{C}-1^{\prime}, \mathrm{H}-3$ to $\mathrm{C}-2$ and $\mathrm{C}-4$, and $\mathrm{H}-4$ to $\mathrm{C}-5, \mathrm{C}-9$, and $\mathrm{C}-10$. The ${ }^{13} \mathrm{C}$ NMR and DEPT $135^{\circ}$ spectra of the compound showed the presence of five olefinic methines and seven quarternary olefinic carbon (12 $s p^{2}$ carbons), two oxymethine, and one methylene. These functionalities accounted for six of the total nine degrees of unsaturation, and the remaining three degrees of unsaturation were consistent with the flavan-3ol structure. Based on the signals of the ${ }^{1} \mathrm{H}$ NMR spectra the compound, the coupling constant between $\mathrm{H}-2 / \mathrm{H}-3\left({ }^{3} J\right)$ was $7.8 \mathrm{~Hz}$, indicated that conformation of $\mathrm{C}-2$ and $\mathrm{C}-3$ were axial-axial, respectively. A detail comparison of NMR spectra of $\mathbf{1}$ to those of catechin (Davis et al., 1996), revealed that the structure were very similar, consequently compound $\mathbf{1}$ was identified as a catechin.

Compounds 2 was obtained as a yellow powder. HR-TOFMS spectrum of $\mathbf{2}$ showed $[\mathrm{M}+\mathrm{H}]^{+} \mathrm{m} / \mathrm{z} 291.0878$ (calcd $\mathrm{m} / \mathrm{z}$ 290.0787), which corresponded to the molecular formula of $\mathrm{C}_{15} \mathrm{H}_{14} \mathrm{O}_{6}$ thus requiring nine degrees of unsaturations. UV spectrum of 2(MeOH) $\lambda_{\max } \mathrm{nm}(\log \varepsilon) 276$ (3.94), IR (KBr) $v_{\max }\left(\mathrm{cm}^{-1}\right) 3330 \quad(\mathrm{O}-\mathrm{H} \quad$ stretch $), 1550 \quad(\mathrm{C}=\mathrm{C}$ aromatics stretch), 1140 (asymmetric C-O-C stretch), 1045 (symmetric C-O-C stretch), 830 (substituted benzene ring). The NMR spectra of 2 was very similar to those of 1 , except ${ }^{3} J$ of $\mathrm{H}-2 / \mathrm{H}-3$ was $1.6 \mathrm{~Hz}$, indicate that the conformation of $\mathrm{C}-2$ and $\mathrm{C}-3$ were axialequatorial, respectively. A detail comparison of NMR spectra of $\mathbf{2}$ to those of epicatechin (Davis et al., 1996) was very similar, consequently compound $\mathbf{2}$ was identified as a epicatechin.

This flavonoid compounds, catechin (1) and epicatechin (2), was isolated in this plant for the first time and support also the occurence of flavonoid compound in Chisocheton genus besides the limonoid as a chemical marker. 


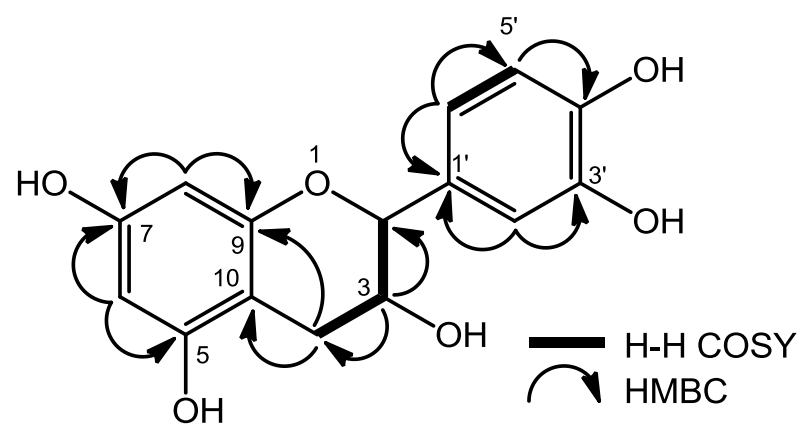

Figure.2. Selected $\mathrm{HMBC}$ and ${ }^{1} \mathrm{H}-{ }^{1} \mathrm{H}$ COSY correlations for $\mathbf{1}$ and $\mathbf{2}$.

Table 1. NMR data (500 MHz for ${ }^{1} \mathrm{H}$ and $125 \mathrm{MHz}$ for ${ }^{13} \mathrm{C}$, in DMSO- $d_{6}$ ) for $\mathbf{1}$ and $\mathbf{2}$

\begin{tabular}{|c|c|c|c|c|}
\hline \multirow{3}{*}{$\begin{array}{c}\text { Position } \\
\text { Carbon }\end{array}$} & \multicolumn{2}{|l|}{1} & \multicolumn{2}{|l|}{2} \\
\hline & ${ }^{1} \mathrm{H}$ NMR & ${ }^{13} \mathrm{C}$ NMR & ${ }^{1} \mathrm{H}$ NMR & ${ }^{13} \mathrm{C}$ NMR \\
\hline & $\delta_{\mathrm{H}}$ (Int., mult, $\left.J=\mathrm{Hz}\right)$ & $\delta \mathrm{c}$ (mult.) & $\delta_{\mathrm{H}}$ (Int., mult, $\left.J=\mathrm{Hz}\right)$ & $\delta \mathrm{c}$ (mult.) \\
\hline 2 & $4.41(1 \mathrm{H}, \mathrm{d}, 7.8)$ & $81.5(\mathrm{~d})$ & $4.66(1 \mathrm{H}, \mathrm{d}, 1.6)$ & $78.5(\mathrm{~d})$ \\
\hline 3 & $3.83(1 \mathrm{H}, \mathrm{dd}, J=7.8,5.5$, & $67.5(d)$ & $4.03(1 \mathrm{H}, \mathrm{dd}, 1.6,4.6)$ & $66.1(\mathrm{~d})$ \\
\hline \multirow[t]{2}{*}{4} & $2.70(1 \mathrm{H}, \mathrm{dd}, 8.3,16.3)$ & $27.2(\mathrm{t})$ & $2.68(1 \mathrm{H}, \mathrm{dd}, 4.5,16.1)$ & $27.9(\mathrm{t})$ \\
\hline & $2.37(1 \mathrm{H}, \mathrm{dd}, 5.5,16.3)$ & & $2.61(1 \mathrm{H}, \mathrm{dd}, 2.8,16.1)$ & \\
\hline 5 & & $156.7(\mathrm{~s})$ & & $156.5(\mathrm{~s})$ \\
\hline 6 & $5.77(1 \mathrm{H}, \mathrm{d}, 2.1)$ & $94.9(\mathrm{~d})$ & $5.78(1 \mathrm{H}, \mathrm{d}, 2.1)$ & $95.0(\mathrm{~d})$ \\
\hline 7 & & $156.3(\mathrm{~s})$ & & $156.1(\mathrm{~s})$ \\
\hline 8 & $5.76(1 \mathrm{H}, \mathrm{d}, 2.1)$ & $94.2(\mathrm{~d})$ & $5.77(1 \mathrm{H}, \mathrm{d}, 2.1)$ & $94.6(d)$ \\
\hline 9 & & $156.0(\mathrm{~s})$ & & $156.0(\mathrm{~s})$ \\
\hline 10 & & $99.5(\mathrm{~s})$ & & $98.7(\mathrm{~s})$ \\
\hline $1^{\prime}$ & & $131.0(\mathrm{~s})$ & & $130.9(\mathrm{~s})$ \\
\hline $2^{\prime}$ & $6.83(1 \mathrm{H}, \mathrm{d}, 1.7)$ & $114.8(\mathrm{~d})$ & $6.82(1 \mathrm{H}, \mathrm{d}, 1.8)$ & $114.6(d)$ \\
\hline $3^{\prime}$ & & $144.9(\mathrm{~s})$ & & $144.9(\mathrm{~s})$ \\
\hline $4^{\prime}$ & & $144.4(\mathrm{~s})$ & & $144.6(\mathrm{~s})$ \\
\hline $5^{\prime}$ & $6.61(2 \mathrm{H}, \mathrm{d}, 8.6)$ & $113.9(\mathrm{~d})$ & $6.60(2 \mathrm{H}, \mathrm{d}, 8.4)$ & $114.0(\mathrm{~d})$ \\
\hline $6^{\prime}$ & $6.65(1 \mathrm{H}, \mathrm{dd}, 1.7,8.6)$ & $118.7(d)$ & $6.63(1 \mathrm{H}, \mathrm{dd}, 1.8,8.4)$ & $118.1(\mathrm{~d})$ \\
\hline
\end{tabular}

\section{CONCLUSIONS}

Two known flavanoid compounds catechin (1) and epicatechin (2) have been isolated from the stembark of Chisocheton pentandrus. This compound was isolated from this plant for the first time.

\section{ACKNOWLEDGEMENTS}

This investigation was financially supported by Lembaga Pengelola Dana Pendidikan (LPDP) and Directorate General of Higher Education, Ministry of Science, Technology and Higher Education, Indonesia (2015-2016 by Supriatno)

\section{REFERENCE}

Agbedahunsi JM, Fakoya FA, Adesanya SA. 2004. Studies on the anti-inflammatory and toxic effects of the stem bark of Khaya ivorensis (Meliaceae) on rats.Phytomedicine. 11(6): 504-508.

Andersen OM, Markham KR. 2006. Flavonoids: Chemistry, Biochemistry, and Applications. New York (US): Taylor and Francis.

Awang K, Lim CS, Mohamad K, Morita H, Hirasawa Y, Takeya K, Thoison O, Hadi AHA. 2007. Erythrocarpines A-E, new cytotoxic limonoids from Chisochetonerytrocarpus.Bioorg. Med. Chem.15(17): 5997- 6002. 
Davis AL, Cai Y, Davies AP, Lewis JR. 1996. ${ }^{1} \mathrm{H}$ and ${ }^{13} \mathrm{C}$ NMR assignments of some green tea polyphenols. Mag. Res. Chem. 34(11): 887-890.

Heyne K. 1982. The Useful Indonesian Plants. Jakarta (ID): Research and Development Agency, Ministry of Forestry.

Inada A, Sukemawa M, Murata H, Nakanishi T, Tokuda H, Nishino H, Iwashima A, Darnaedi D, Murata J.1993. Phytochemical studies on Maleaceous Plant. Part VIII. Structures and Inhibitory Effects on EpsteinBarr Virus Activation of Triterpenoids from Leaves of Chisocheton macrophyllus King. Chem. Pharm. Bull. 41: 617-619.

Joshi MN, Chowdhury BL, Vishnoi SP, Shoeb A, Kapil RS. 1987. Antiviral activity of (+)odorinol.Planta Medica. 53: 254-255.

Katja DG, Farabi K, Nurlelasari, Harneti D, Mayanti M, Supratman U, Awang K,Hayashi H. 2016. Cytototoxic constituents from the bark of Chisocheton cumingianus (Meliaceae).Journal of Asian Natural Products Research. 19(2): 194200.

Lim CS. 2008. Master Science Thesis, Department of Chemistry, University Malaya, Malaysia.
Mabberly DJ, Pannel CM. 1989. Meliaceae in Tree Flora of Malaya, vol 4, Forest Research Institute Malaysia, Kuala Lumpur, Malaysia.

Mohamad K, HirasawaY, Lim CS, Awang K, Hamid A, Hadi A, Takeya K, Morita H. 2008. Ceramicines a and walsogyne a, novel limonoids from two species of Meliaceae. Tetrahedron Letter.49: 42764278 .

Mohamad K, HirasawaY, Litaudon M, Awang K, Hamid A, Hadi A, Takeya K, Ekasari W, Widyawaruyanti A, ZainiNC, Morita H. 2009. Ceramicines B-D, new antiplasmodial limonoids from Chisocheton ceramicus. Bioorg. Med. Chem.17(2): 727-730.

Najmuldeen IA, Hadi AHA, Awang K. 2011. Chisomicines A-C, limonoids from Chisocheton ceramicus. Journal of Natural Products. 74(5): 1313-1317.

Nurlelasari, Katja DG, Harneti D, Wardayo MM, Supratman U, Awang K. 2017. Limonoids from the seeds of chisocheton macrophyllus. Chemistry of Natural Compounds.53(1): 83-87.

Vossen VD, HAM, Umali BE. (Editors). 2002. Plant resources of south-east Asia No. 14, vegetables oils and fats. Bogor (ID): Prosea Foundation. 